\title{
Watershed Management \& Treatment of Agriculture Land (A Case Study of Dhaulpur District)
}

\author{
Dr. Gambhir Singh \\ Assistant Professor \& Head Dept of Geography, Shree Agrasen Mahila PG College, Bharatpur
}

\section{Introduction}

Agriculture production in Rajasthan in view of its poor endorsement of water resourced in critically dependent on the vagaries of monsoon. Only one fourth of the cultivated area is irrigated of which nearly two third is dependent on ground water sources as well. Tube wells etc. the over $90 \%$ of the state's cultivated area is dependent on rainfall. Uncertainly of rainfall as well as its unequal distribution is the primary reason for the poor productivity of unirrigated land. Traditional methods of cultivation cannot optimally utilize the rain water and in the process precious fertile so9il gets washed off with water leading to reduction in productivity of un irrigated land.

Due to above mentioned reason in Rajasthan, soil and moisture conservation by adopting watershed development techniques is of critical importance to bring growth as well as stability in agriculture production from rainfed areas. To provide the much required thrust for the development of rain- fed agriculture on watershed basis the state Govt. has set up a separate department of watershed development and soil conservation in January, 1991. Now a days programmes of different type watershed are running mostly in all district of Rajasthan.

Deterioration of natural resources of any region can be contained and managed on sustainable basis by adaptation of an integrated development plan on watershed basis. In this approach, development is not only confined to agriculture land alone but also covers all other areas which are put to different uses or are lying a barren lands. The programme involves improvement measures for areas already under use of ameliorative measures for lands that are not usable at present due to existence of some problems.

\section{Watershed Development in Dhaulpur District}

State Remote sensing Application center ( SRSAC ) jodhpur, delineated thje whole Reajasthan into 13 riover valley catchments for the codification of watersheds of watersheds. In the process according to ( SRSAC ) delineation the area of the Dhaulpur District comes under Banganga and Chambal rier Valley catchment . Different type programmes for the watershed managemtn soil conservation are came into existence actually since 1997. Some of them have been completed and other are under progress.
There are Different techniques which are being beneficial for treatment of agriculture land including arable and non arable.

\section{Treatment of Arable Land}

The conservation measure on arable Lands are meant to reduce or present the sheet and gullies erosion along with increasing moisture regime in the soil. Which is the great need of Dhaulpur District. These also check ingress of finger gullies in the agricultural lands. The important principal top may be kept in view when the planning measures are Increasing the time of concentration and their by increasing the opportunity for the soil to absorb the run of water and hold it in soil profile. Intercepting the long slopes by dividing them into several short ones so as to reduce the velocity to less then critical velocity and Protection against damage due to excessive runn off. To achieve the goal different activities are taking place.

\section{Contour Vegetative Barriers}

Contgour vegetative barrier (Hedge) across the slope is an effective and cheap, assures for water conservation The vegetative material shall have to be selected our of the locally available bushes plants or new species shall have to be introduced in the projected area. The elected vegetable material should have the followings qualities. Should be perennial and capable of forming a hedge . Should not be plan table fodder to the animals. Should not spread as used in the culgture able areas. The hedge should spread at the ground level so that the run off can ooze out in the entire length of the hedge. Khas, Moonja, Kheep etc. are the recommended species of plants for vegetative barriers. Gap filling has to be done in next monsoon seasons. A small earthen bund is to be provided to facilitate initial establishment of the vegetation.

Anti termite treatment is also to be provided Contour bounding Contour bunding ( A series of mechanical barriers across the slope ) has found most effective and widely practicised measure for preventing erosion in different soil conditions when installed at calculated horizontal interval with permissible deviations.

These bunds divide longs slopes into smaller ones. They are provided to hold large part of rainfall in the fields to check erosion and conservation sufficient moisture to grow crops and fodders etc. they also prevent washing away of manure and fertilizer applied to the fields contour bunds are constructed on such lands where slope does not exceed. 


\section{International Journal of Science and Research (IJSR) \\ ISSN (Online): 2319-7064}

Index Copernicus Value (2016): 79.57 | Impact Factor (2015): 6.391

Water injectors are used to economies the use of water for plants water is injected in to the root zone of the plant.

\section{Dry Land Farming Techniques}

Dry land farming is a system of soil and crop management in regions of low erratic and uncertain rainfall. Each such area has is its peculiar rainfall, soil conditions and cropping practices in Dhaulpur district following techniques are taking place. Contour farming - Carrying out farming operation, namely ploughing, palnting and cultivating along contours is know as contour farming. By doing so, every furrow acts as a miniature reservoir to held the run off from intervening space and gives increased time and opportunity to the soil to absorb as much as rain water as possible for storage and make available to the crop later on. This method will be effective only on land with very mild slopes but for greater slopes it should be supplemented with other engineering measures. Contour strip cropping - It is a system of growing different crops in alternating contour strips, sch that they serve as vegetative barriers in controlling erosion and runoff and tehere by maintaining fertility \& soil. Suitable width or erosion permitting and erosion resisting crops have to be adopted on different slopes. Crops with maximum canopy cover like cultivated lagumes give better protection to cultivated land against erosion than clean cultivated crops. Stable mulching - Surface mulches are used to prevent soil from blowing away by wind or washing away by run off water and to reduce evaporation, to increase infiltration capacity of soil, to keep dawn weeds, to improve soil structures and eventually to increase crop yield. The plastic films may be used in crops as well as trees to prevent evaluation of moisture. Khana bunding - It is practiced in the light soil area with less then $300 \mathrm{~mm}$ annual average rainfall. Locally available dry vegetation like munja are put is 3 tiers, about 20 to $25 \mathrm{~m}$. apart in rows acroos the wind direction, the soil is dumped on each of the layer separately. Shelter belts - The problems of wind erosion is severe in most part of Rajasthan including study area. The C.A.Z.R.I. has recommended planting of shelter across the wind direction to protect agricultural lands, orchards. Canals etc. from hot winds and moving sands. These belts may be of five or seven rows of tress. The trees planted staggered in rows at $5 \mathrm{~m}$. Apart row to row and at 3 to $5 \mathrm{~m}$ apart plant to plant and water conservation but also it gives fuel and makes ecological balance. The vegetations which are used in shelter belts. For central Row - Acacia tortillas, prosopis juliflora cassia siamea. Flank row - Dishrostachys glomeratle, Acasia senegul, colophos permum mopaue. Outer row - Zizyphus nummularia, casis auricu late, saccharum bangalense, Aguae etc. Khood Making - To control the runoff the rain water. Opposite the slope in contour khood are made. They prevent the flow of rain water and soil erosion and conserve the equal moisture in all part from and nutrient of the fields also present from being flown out. Bench Terracing - Bench Terracing Method of agriculture on hilly slopes is very ancient. It is not only means of minimizing the slope but also it contains the equal moisture in. soil on different heights. Terraces are constructed opposite the slope and parallel the contours. Bench terracing farm are three types which are table slope, inner side slope \& outer side slope. Tanks - Tanks is a covered masonry runoff storage tank. It is also an age old practices in the desert areas and is used for harvesting surface water for life sawing irrigation and drinking purposes. The Tanks collects runoff water from artificial catchment constructed around it. Sand Dune Stabilization Movement of sana dunes needs stabilization because it poses serious threat to the productive agriculture lands of micro winds breaks on the wind ward side of the sand dune in parallel strips or in a chess board pattern. Plantation is done between these checks. Farm pond - Construction of some farm ponds may be necessary in arable areas so that runoff is collected for utilization of watering of the plants at a later stage. The farm ponds can be lined with either plastic pilot theme films or mud cement plaster. Farm pond stores the access rain water and it increased the ground water level with the filling the necessity of local people. To improve the income \& nutrition level of the cultivators. Organic farming System / compost pits - Organic manure is decomposed agricultural waste and cow dung. Which is applies in the field in place of chemical fertilizers. It is cheaper locally available and without any kind of side effect.

\section{Treatment of Non Arable Lands}

In the non arable areas, the water conservation is required to sustain afforestation activities and pastgure them is compulsory because they produce the water for drinking, irrigation, industries and livestock to villagers. New techniques should also be used in their maintenance. crop cycle - The accurate method of crop cycle, controls the soil erosion and preserver the productivity of land. So following points are considerable during the crop cycle. As possible land coverer crops should be selected in crop cycle which should be useful economically as well as barrier for land erosion. The corps should be able to bind the soil by roots such as different grass of dalhan plants. Dalhan crops should be selected because they increase the productivity of land and improve the soil texture with increasing the absorbing power of land. Mixed farming is also in crop cycle in which one crops should be straight growing like mustard and other should be surface coverer like gram or other dalhan crops such as ground nut with Jwar, Urad, Moong, with Gwar etc.

Grass Breeding - Grass Breeding between the gap belt helps to contrl the soil erosion because the roops of the grass bind the soil together and over cover of grass preserve it from being washed away by heavy rain with controlling the flowing speed of water. Slow flowing of water is the good means to absorbing the water of land. Dug out Pond - It is a structure of water storing, which is used to stop, flow of excess water, which could be used, in dry season or gap in rain or in condition of drought. It is constructed by dug out the ground or by making the sail bund around the low point where water could be stored. Generally they are constructed in the square shape with terraces but its shape can be changed according to water storing power of it. Ancient Indian villages were full of dugout ponds. khandin Structure - Khandin is wall of soil which is constructed opposite the slope with suitable height, Khandin one side stores the water there had a mettled bear to flow out the khadins excess water. Khandin is the useful for both crops " Ravi and Kharif' is there is enough water for irrigation. There could be wheat, gram etc. in Ravi crop. The process of storing the water on low sloppy land it increases the underground water

\section{Volume 6 Issue 12, December 2017}




\section{International Journal of Science and Research (IJSR) \\ ISSN (Online): 2319-7064}

Index Copernicus Value (2016): 79.57 | Impact Factor (2015): 6.391

level or if land contains good moisture it can produce good Ravi Crop without irrigation.

Repair of present strong means like, spear, chadein, tanks vegetation barriers, contour bunds, etc should maintained form time to time. Preservation of development usually this land falls under the land capability classes VI to VII. They have one or more limitations of depts. Of soil, slope, erosion etc. which make them unsuitable for regular cultivation of agricultural crops, although they have a great potential for producing fodder, fuel minor fruits etc. To optimize the production of vegetation, soil and water production of vegetation, soil and water conservation measures based on topographical and soil survey reports are to be taken up to reduce soil erosion and increase moisture regime.

Diversion drains - The soil and water conservation measures in non arable area will reduce the total runoff considerable. Even then due to erratic short rainfall conditions and high intensity rains, there will always be some excess run off water which rains there shall damage arable lands dawn below if not checked on the periphery of the non arable areas. Therefore diversion at conveying excess runoff safely to some natural strength so that arable lands are protected. Diversion drain are cut off line between the non arable and the arable. They should be constructed with a non erosing and non silting velocity. For computing the runoff rational formula :

$Q=\frac{\text { C.I.A }}{360}$ is to be used

Where ' $Q$ ' is peak discharge in cusec $c$ is weighted runoff coefficient ' $I$ ' is intensity of rainfall of 10 years. Recurrence interval in $\mathrm{m} / \mathrm{hr}$. and 'A' catchment area in hectares.

The cross sectional area of the diversion drain is to be designed to carry the calculated run off using formula : ' $Q$ ' $=\mathrm{A}$. V. where ' $\mathrm{Q}$ ' is a given above. ' $\mathrm{A}$ ' is cross sectional area in sqm and ' $\mathrm{y}$ ' is the designed velocity in met. Non erosive grade of divisional ditch is calculated by using manning formula.

$$
\mathrm{V}=\frac{\mathrm{R}^{2 / 3} \mathrm{~S}^{1 / 2}}{\mathrm{~N}}
$$

Where

$\mathrm{V}=$ permissible velocity

$\mathrm{N}=$ roughness coefficient

$\mathrm{R}=$ hydraulic radius

$\mathrm{S}=$ Slope is percentage

A filter strip consisting of rows of trees and bunched can be constructed instead of diversion ditch in some situations specially where run off is not heavy.

Continuous contour V ditches - They are constructed on contours by excavating a trench and forming found on down steam of the trench. This ditch across the slope breaks the length of slope and thereby checks the velocity of runoff. The cross section of a model $\mathrm{V}$ ditch is given in fig. The excavated soil shall dumped on the down steam side with proper vegetative cover in such a way that a continuous ridge is formed having a base width of $30 \mathrm{~cm}$ and a semicular height of $25 \mathrm{~cm}$. In case continuity of the contour trenches is not possible, and hooks should be provided. Equalizers at
$10 \mathrm{~m}$ interval area provided. Staggered Trenches Continuous contour trenches may be more effective in lands having some soil cover with less slopes, in between the trenches sub-soiling is done to increase the infiltration rate reducing the runoff and its velocity contour. Contour vegetative hedge on non arable lands are to be installed in the $\mathrm{V}$ ditch so that moisture is available to the plants for their growth. The selection of the vegetative hedge must be done on the basis of agro-climatic conditions. Usually the hadge should be planted in every $4^{\text {th }}$ ditch. It is recommended that the forest species suitable for the area must be planted in the pits dug out in the $\mathrm{v}$ ditches so that proper moisture conditions are available for the growth of the tress. Between the trenches, grasses they are to be grown so that it provides a complete vegetative cover on the land. In times to come these vegetative measures shall check splash erosion and check the velocity of run off.

Sub-soiling or chiseling - From times immemorial no crops have been takes up in non arable areas and so no soil working has over been done in these lands. Therefore these are virgin and compact lands with negligible infiltration rate, resulting in great amount of runoff. In filtration and percolation rates of these soils can be increased in manifold by use of sob soil or chisel plow. The chisel plow is attached with tractor of about 50 H.P. which should be used just after first rains on contours at a horizontal interval of 2 to 3 , meters depending upon the horizontal interval of contour ditches. For subsequent construction of $\mathrm{v}$ ditches or pits for plantation, the chisel plow can be used up to November and for loosening of soil when the depth of working would be about $50 \mathrm{~cm}$. Stone wall terraces - Stone wall barriers constructed along contours in hilly tracts are good erosion control measures. These are particularly suitable in area where depth of soil is shallow. Over the year the land between the two parts gradually gets leveled or the slope is reduced to facilitate cultivation in an improved manner. On the toe of the terrace, vegetative barrier is put to strengthen the wall and allow excess run off safely to flow over wall at selected places. Shallow drainage-lines structures may have to be constructed in non-arable areas depending upon various factors likes runoff, intensity of rain fall topography, soil characters vegetative covers etc. Water harvesting structure - In spite of soil and water conservation works executed in non-arable, arable lands and in the drainage lines, there shall always be some run off going out of the watershed area, This water can be utilized gainfully if water harvesting structures are constructed in the down steam areas. These include anicuts, khadins and tanks their designs shall depend upon specific site conditions and therefore planning and designing shall have to be done for individual structures after carrying out detailed investigations.

\section{Conclusion}

In short, present study is an effort to evaluate the achievement and utility of watershed management programs in Dhaulpur district specially in the field of agriculture land treatment. There are a lot of techniques which are directly treating agriculture land as well as other benefits such as increasing in ground water level etc.

Volume 6 Issue 12, December 2017 


\section{References}

[1] ,dhd'r xzkeh.k fodkl ;kstukvksa ds v/khu tyxzg.k $\{k s=$ fodkl fn'kk funsZ'k 1997 \& fof'k"V ;kstuk,sa ,oa ,dhd'r xzkeh.k fodkl foHkkx] jktLFkku ljdkj] t;iqj $1 / 4$ $i$ - $3 \& 7 \frac{1}{2} A$

[2] tkV foj/kh pan $1 / 42000 \quad 1 / 2$ jktLFkku esa tyxzg.k izca/ku] jktLFkku ds iks"k.kh; fodkl ds fy, leL;k,sa ,oa IEHkkouk,sa A

[3] tyxzg.k \{ks= fodkl iqfLrdk] LoPNrk ty ,oa lkeqnkf;d LokLFk; ifj;kstuk] mn;iqj A

[4] Technical Manual for watershed development, Watershed Development and soil conservation department Got. Of Rajasthan, Jaipur.

[5] Watershed Development in Rajasthan 'Activities and Achievements', Department of Watershed development and soil conservation Rajasthan, Jaipur.

[6] Annual report ( 2001 directorate off watershed development \& soil conservation, Govt. of Rajasthan, Jaipur, Page $6-9$

[7] Watershed development guidelines (May 2001) directorate of watershed development and soil conservation, Govt. of Rajasthan, Jaipur, Page $27-30$.

[8] Tanning book ( 2000 ) Directorate of watershed development \& soil conservation, Govt. of Rajasthan, Jaipur, Page $7-14$

[9] Hanumanth Rao committee ( 1994 ) : Guidelines for watershed development, ministry of rural development, Govt. of India, New Delhi, Page 50 - 57.

[10] Yojna ( August, 2000 ) Publication, New Delhi, Page 58 $-59$.

[11] Mohammad. A (1997) : Statistical Methods in Geographical studies, Rajesh Publication, New Delhi Page 13- 14.

[12] Indian farming: watershed basis agricultural development on vol, XXXIX No. 9 Dec. 1989.

[13] Rao, C.H.H. (2000) : Watershed development in India : Recent experience and Emerging issues, Economics and Political weekly, Vol 35, No. 45. 